\section{Psykoanalyse og politikk}

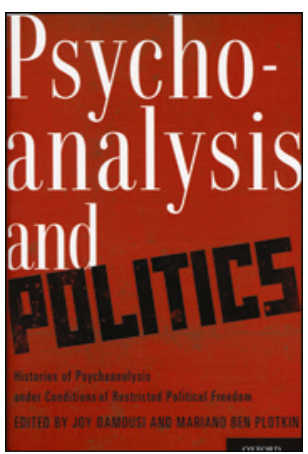

Joy Damousi, Mariano Ben Plotkin, red Psychoanalysis and politics

Histories of psychoanalysis under conditions of restricted political freedom. 288 s. Oxford: Oxford University Press, 2012. Pris GBP 33 ISBN 978-0-19-974466-4

Joy Damousi, australsk historiker og filosof, og Mariano Ben Plotkin, argentinsk samfunnsforsker, er redaktører. De har satt seg fore å undersøke psykoanalysens utvikling under autoritære politiske forhold. Det grunnleggende spørsmålet er: Under hvilke politiske forhold kan psykoanalysen eksistere og eventuelt blomstre? Mange ville trodd at psykoanalysen ikke kunne leve i autoritære samfunn.

Den skjebnen psykoanalysen fikk mellom de to verdenskrigene i forskjellige land med autoritært styre, synes å bekrefte et slikt syn. Psykoanalysen var bannlyst i Stalin-Russland, den vokste aldri frem i Fascist-Italia, og det psykoanalytiske samfunnet i Tyskland gikk i oppløsning under naziveldet. På den annen side blomstret psykoanalysen opp i det demokratiske Amerika og fikk et visst fotfeste i England og Frankrike på 1930- og 40-tallet.

Men bildet er nok mer komplisert. Går vi til Latin-Amerika, ser vi at psykoanalysen ikke ble forfulgt verken av de autoritære populistregimene fra 1930- og 40-årene eller av de autoritære militærdiktaturene på 1960- og 70-tallet.

I Ungarn sto psykoanalysen relativt sterkt før siste verdenskrig med lederfigurer som Sandor Ferenczi, men verken admiral Horthy, med sitt halvfascistiske styre, eller tyskerne direkte motarbeidet psykoanalysen her. I Spania fikk psykoanalytikerne praktisere under Franco- regimet og anledning til å delta i offisielle psykiatriske møter. De beholdt til og med sine universitetsstillinger i Barcelona. Når psykoanalysen fikk leve i Spania under Franco, var det nok fordi ledende psykoanalytikere var forsiktige og holdt en lav politisk profil. Det samme skjedde i Italia under den italienske fascismen. Populær ble psykoanalysen i Spania først da demokratiet gjenoppsto i 1970årene, ikke minst under påvirkning av utvandrede argentinere.

I Argentina og Brasil har psykoanalysen dominert ikke bare psykiatrien, men det alminnelige kulturelle klimaet helt frem til i dag. I løpet av de siste 50 årene har Argentina vært hovedsete for det kanskje største psykoanalytiske samfunnet i verden. Antall praktiserende terapeuter i Argentina har vokst voldsomt de senere årene, til om lag 200 terapeuter per 100000 innbyggere, altså én per 500 innbyggere. Det er ikke knyttet noe tabu til å søke psykiatrisk hjelp, og psykoanalyse er ikke knyttet til den øvre middelklassen, men er for alle. Således får fagorganiserte arbeidere gjerne dekket flere timer psykoanalytisk behandling hos psykolog eller psykiater gjennom offentlige forsikringer. Paradoksalt nok skjedde oppblomstringen av psykoanalysen i Argentina på 1960- og 70-tallet da landet ble styrt av et grusomt repressivt militærregime som forsøkte å kontrollere både folks politiske og private atferd.

Hvordan kan man forklare et slikt fenomen? Forfatterne gjør et hederlig forsøk, men lykkes ikke alltid helt. I USA er kanskje bildet mer komplisert enn hva man ofte får inntrykk av. Psykoanalysen vokste seg sterk og slo igjennom i amerikansk psykiatri på 1950tallet, kanskje den mørkeste tiden i amerikansk demokratisk historie.

Dette er en interessant bok med gode oversikter, men ikke alltid like dyptgående analyser.

Einar Kringlen

Psykiatrisk institutt, Vinderen

Universitetet i Oslo

\section{Ny omfattende bok i moderne medisinsk statistikk}

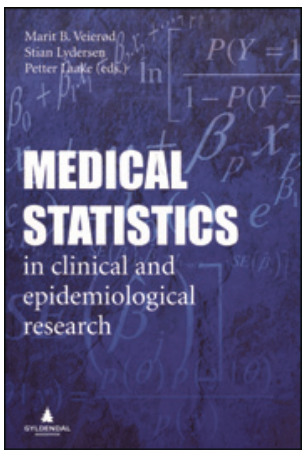

\author{
Marit B. Veierød, Stian Lydersen,
}

Petter Laake, red.

Medical statistics in clinical

and epidemiological research

714 s, tab, ill. Oslo: Gyldendal Akademisk,

2012. Pris NOK 575

ISBN 978-82-05-39959-4

Det er et stadig økende krav til å bruke mer avanserte statistiske metoder innen klinisk og epidemiologisk forskning. Basert på en gjennomgang av artikler i New England Journal of Medicine i 2004-05 ble det estimert at et typisk innføringskurs i statistikk kun gjør leseren i stand til å forstå statistikken i om lag $20 \%$ av artiklene (1).

Denne boken er ingen innføringsbok i medisinsk statistikk, men en bok for ph.d.-studenter og forskere med god bakgrunnskunnskap i statistikk som ønsker en bred oversikt over metoder som brukes i dagens forskning. Den er matematisk orientert, men ulike statistiske metoder illustreres gjennom gode eksempler fra medisinsk forskning.

De 20 kapitlene er skrevet av dyktige nasjonale og internasjonale eksperter. De første ni kapitlene er skrevet for å kunne leses sammenhengende, mens de resterende kan leses uavhengig av de andre.

Redaktørene har hatt et omfattende arbeid med å koordinere nomenklatur og metodologi i de mange bidragene. Dette har de stort sett lyktes med, men med så mange ulike aktører involvert vil det bli ulike tilnærminger. Et eksempel på dette er beskrivelsene av analysestrategier for multivariabel analyse.

Boken skiller seg fra andre tradisjonelle statistikkbøker ved at forfatterne legger vekt på mange nye metoder som er i ferd med å få en fremtredende rolle innen medisinsk forskning. Eksempler på dette er kapitler om «mixed models», repeterte målinger, genetisk statistikk og manglende data. Forfatterne dekker også mer tradisjonelle metoder som lineær og logistisk regresjon, i tillegg til overlevelsesanalyser. Personlig likte jeg kapitlet om årsakssammenhenger og bruk av grafiske plot for å beskrive disse. Slike plot er nyttige redskaper for å analysere og kommunisere komplekse sammenhenger som involverer flere variabler.

Jeg anbefaler boken til alle som driver med klinisk eller epidemiologisk forskning.

\section{Pål Romundstad}

Institutt for samfunnsmedisin

Medisinsk teknisk forskning

Norges teknisk-naturvitenskapelige universitet

\section{Litteratur}

1. Horton NJ, Switzer SS. Statistical methods in the journal. N Engl J Med 2005; 353: 1977-9. 